\title{
3: 48204805-48173672
}

National Cancer Institute

\section{Source}

National Cancer Institute. 3:48204805-48173672. NCI Thesaurus. Code C41917.

Physical location of CDC25A_Gene 